\title{
Interpretation and Application of Article 98 of the Rome Statute
}

\author{
Phd.c. Mimoza Sadushaj \\ Tirana University, Faculty of Law, Albania
}

Phd. Saimir Shatku

Tirana University, Faculty of Law, Albania

Phd.c. Flori Pustina

Tirana University, Faculty of Law, Department of Criminal Law, Albania

Phd.c. Erdi Kuka

Tirana University, Faculty of Law, Albania

Msc. Geraldo Taraj

Doi:10.5901/ajis.2017.v6n1p141

Tirana University, Faculty of Law, Albania

\begin{abstract}
Many high officials accused for crimes falling under the ICC (International Criminal Court) Statute, like the leader of Sudan Omar al-Bashir, have defended themselves against ICC prosecution using their State, diplomatic or Head of State immunity and there so invoking Art. 98 of the ICC Statute. This paper is to clarify all the incorrect claims, which abusively use Art. 98, to justify the objection of ICC prosecution in cases where the defendant has state, Head of State or diplomatic immunity due to his official capabilities. The paper conclusions will deal with the proper interpretation and application of this article and the reasoning of why Head of States and other high officials cannot be defended from the ICC prosecution using their immunity as an argument.
\end{abstract}

Keywords: ICC, Rome Statute, Art.98, immunity, International Criminal Law,

\section{Introduction}

This paper is actuated by several cases in international jurisprudence, such us the Omar Al-Bashir case of International Criminal Court ${ }^{1}$, the Arrest Warrant Case of the International Court of Justice ${ }^{2}$, The Blaskić Decision of International Criminal Tribunal for the Former Yugoslavia ${ }^{3}$, the Pinochet Case of House of Lords ${ }^{4}$ etc. in which the concept of invoking immunity to oppose a criminal prosecution has been extensively addressed by the Courts and the Parties participating therein.

\footnotetext{
1 Situation in Darfur, Sudan in the Case of the Prosecutor v. Omar Hassan Ahmad Al Bashir, Decision Pursuant to Article 87 (7) of the Rome Statute, ICC-02/05-01/09-139.

${ }^{2}$ Arrest Warrant of 11 April 2000 (Democratic Republic of the Congo v Belgium), 41 ILM (2002) 536.

3 Prosecutor v. Tihomir Blaskić, Judgment, IT-95-14-108bis: Blaskic (Interlocutory), 29 October 1997.

${ }^{4}$ R. v Bow Street Stipendiary Magistrate and Others, Ex parte Pinochet Ugarte (No. 3), 24 Mar. 1999, 38 ILM (1999) 581.
} 
In Arrest Warrant, the ICJ argues that sitting Heads of State or governments and foreign ministers are protected by customary international law from prosecution by domestic courts, regardless of their lack of immunity before international courts. ${ }^{5}$ And some arguments even say that the prosecution of a person entitled with immunity would be possible just in the case of Security Council's engagement in the case of chapter VII measures and mandate or claiming that Article 98 requires the Court to seek an agreement of a third state to prosecute certain persons. ${ }^{6}$

One of the latest reaction and opposition of ICC prosecution invoking Art.98 has been made by the African Union in account of Malawi and Chad in the case of Omar Al-Bashir vs. the Prosecution. The reaction of the African Union Commission expressing its deep regret on the case of Al-Bashir, which claimed the decision of the Court, has the effect of:

i) "Purporting to change customary international law in relation to immunity ratione personae;

ii) Rendering Article 98 of the Rome Statute redundant, non-operational and meaningless;

iii) Making a decision per incuriam by referring to decisions of the African Union while grossly ignoring the provisions of Article 23 (2) of the Constitutive Act of the African Union, to which Chad and Malawi are State Parties, and which obligate all AU Member States 'to comply with the decisions and policies of the Union'."'

So, simplifying the analysis and the interpretation of the situations Art.98 refers to and the misuse of International Customary law, all it seems too easy for the perpetrators of the most serious crimes sanctioned by the Rome Statute, to trick and avoid the prosecution by the ICC. Although, seemingly that simple on a first look the reality of the case herein is completely different. In this paper we will try to make a correct analysis of the circumstances Art.98 refers to in order to reach a conclusion of how should be the proper interpretation and application of Art. 98 of the Rome Statute.

\section{Article 98 (1), Head of State Immunity and the International Approach of this Issue}

According to Art. 98 (1) of the Statute, States Parties can refuse the cooperation requests of the ICC on arresting and surrendering a person citizen of a third State, if the Court with this request is asking the State Party to act inconsistently with international law. In this case, referring to Art. 98 (1), international law is affording to this person State or diplomatic immunity, thus the State Party cannot continue with further actions in fulfilling the cooperation request, unless the Court can first obtain the cooperation of the third state for the waiver of the immunity.

Recent development in international law suggests that functional immunity, ${ }^{8}$ which is immunity for people that perform certain functions of a state, whilst it may be available as a defence to prosecution for local or domestic crimes or civil liability, it is not a defence to an international crime which includes; crimes against humanity, war crimes and genocide this was developed in the jurisprudence of the International Criminal Tribunal for the former Yugoslavia (ICTY) particularly in the Karadzic, Milosevic and Furundzija cases. This was also the agreed position as between parties in their pleadings in the International Court of Justice case concerning the Arrest Warrants of 11th April 2000 (Democratic Republic of Congo v Belgium). ${ }^{9}$ The reason given for unavailability of this immunity as a defence is straightforward;

1. Genocide, War crimes and crimes against humanity are not acts a state.

2. The jus cogens nature of international crimes cannot be allowed to be eroded by immunities.

Sir Arthur Watts' scholarly opinion that was even cited by the House of Lords in the Pinochet case ${ }^{10}$ observed that "The idea that individuals who commit international crimes are internationally accountable for them has now become an accepted part of international law. ${ }^{11}$ In conclusion he says "It can no longer be doubted that as a matter of general customary international law a head of state will personally be liable to be called to account if there is sufficient evidence

\footnotetext{
${ }^{5}$ Arrest Warrant of 11 April 2000 (Democratic Republic of the Congo v Belgium), 41 ILM (2002) 536, p. 551, para. 61

${ }_{6}^{6}$ Prost and Schlunck, in Triffterer Commentary, Article 98 MN 4, 6. In: Andreas L. Paulus , Legalist Groundwork for the International Criminal Court: Commentaries on the Statute of the International Criminal Court, EJIL (2003), Vol. 14 No. 4, p. 856.

7 African Union Press Release No 002/201 (9 January 2012) available at http://www.au.int/en/sites/default/files/PR-\%20002\%20ICC\%20English.pdf (last visited 20 March 2015).

8 Jürgen Bröhmer, Diplomatic Immunity, Head of State Immunity, State Immunity: Misconceptions of a Notorious Human Rights Violator, 1999, LIJL

${ }^{9}$ Arrest Warrant of 11 April 2000 (Democratic Republic of the Congo v Belgium), 41 ILM (2002) 536.

10 See also Regina $v$ Evans and Another and the Commissioner of Police for the Metropolis and Others Ex PartePinochet(On appeal from the Divisional court of the Queen's Bench Divison). Also found at http://www.parliament.thestationeryoffice.co.uk/pa //id199899jd990324/pino2.htm (last visited on 22 March 2015)

${ }^{11}$ Arthur Watts, The Legal position in international Law of Heads of states, Heads of Government and Foreign Ministers at Pg. 82.
} 
that he authorized or perpetrated such serious international crimes. The question then becomes not whether heads of states can be tried but when and how?"12

In the Arrest Warrants case ${ }^{13}$ the ICJ listed four scenarios where immunity could not apply and one of them is when the particular individual is being tried before 'certain international courts with jurisdiction' specifically mentioning the ICTY, ICTR and the ICC.

This line of reasoning did not stop there. 2 years later, replying in part to the obiter dictum referred to above on 31st May 2004, the Special Court of Sierra Leone (SCSL) unanimously denied the cloak of immunity to the ex-Liberian president Charles Taylor Ghankay even though his criminal proceedings commenced while he was still head of state.

The SCSL categorized itself among the 'certain international courts with jurisdiction'. The court went ahead to state that had it upheld Taylor's immunity claim it would have nonetheless proceeded to re-issue a fresh warrant of arrest since Taylor at the time of the decision had ceased to hold office. ${ }^{14}$

Furthermore, the approach that UN has embraced about this issue is that: "the refusal by states to cooperate in the arrest, extradition, trial, and punishment of persons guilty of war crimes and crimes against humanity is contrary to generally recognized norms of international law." 15

This is an issue which has received replies since the beginning of international criminal justice (the contemporary meaning of it) existence. Thus, both international criminal law, including Rome Statute and all other precursor international criminal statutes and case law of the ICC, clearly emphasize that any kind of immunity, including that of Head of State immunity, shall not prohibit the Court from exercising its jurisdiction. The first clue of this concept it is implied in the Preamble of the Statute, which states that: "the most serious crimes of concern to international community as a whole must not go unpunished, and the determination of the Court, to put an end to impunity for the perpetrators of these crimes and thus to contribute to prevention of such crimes."16 This constitutes one of the "core goals"17 of the ICC. The Court and the Statute, in order to fulfil this mission, provides and explicitly expresses in Art. 27 (Irrelevance of official capacity) of the Statute. This Article reads as follows:

i. "This Statute shall apply equally to all persons without any distinction based on official capacity. In particular, official capacity as a Head of State or Government, a member of a Government or parliament, an elected representative or a government official shall in no case exempt a person from criminal responsibility under this Statute, nor shall it, in and of itself, constitute a ground for reduction of sentence."

ii. "Immunities or special procedural rules which may attach to the official capacity of a person, whether under national or international law, shall not bar the Court from exercising its jurisdiction over such a person." 18

In addition, according to the case law of the Court, it is important to be kept in mind that: "the applicable law before the Court has held that, according to article 21 of the Statute, those other sources of law provided for in paragraphs (I) (b) and (I) (c) of article 21 of the Statute, can only be resorted to when the following two conditions are met: (i) there is a lacuna in the written law contained in the Statute, the Elements of Crimes and the Rules; and (ii) such lacuna cannot be filled by the application of the criteria of interpretation provided in articles 31 and 32 of the Vienna Convention on the Law of the Treaties and article 21 (3) of the Statute."19 In this conclusion the Court clearly highlights that the use of other sources of law, such as international customary law, should be secondary, always when the interpretation of the Statute provisions may be equivocal.

The insignificance of immunities or other special procedures in the framework of international criminal justice, has found expression not only in the present Statute of International Criminal Court, but even in earlier Statuses of international criminal courts or tribunals, since World War I. The Court itself, on a previous decision, when doing the historical interpretation of this issue, notably held that: "immunity for Heads of State before international courts has been

\footnotetext{
12 lbid pg. 84

${ }^{13}$ DRC V Belgium

${ }_{14}$ Prosecutor v Charles Ghankay Taylor case No.SCLSL-2002-01-1 Decision on immunity from jurisdiction, 31st May 2004.

15 See George William Mugwanya, Expunging the Ghost of Impunity for Severe and Gross Violations of Human Rights and the Commission of Delicti Jus Gentium: A Case for the Domestication of International Criminal Law and the Establishment of a Strong Permanent International Criminal Court, 8 MICH. ST. U. C. L. J. INT'L L. 701, 757, 759, 778 (1999).

${ }^{16}$ Rome Statute of International Criminal Court, Preamble, July 17, 1998.

17 See ICC-02/05-01/09-139, 12-12-2011.

${ }^{18}$ Rome Statute of International Criminal Court, art. 27, July 17, 1998.

19 ICC-02/05-01/09-139, 12-12-2011, at 3/22.
} 
rejected time and time again dating all the way back to World War I." 20

Therein, this Chamber (Pre-Trial Chamber I, on the "Decision pursuant to Article 87(7) of the Rome Statute on the Failure by the Republic of Malawi to Comply with the Cooperation Requests Issued by the Court with Respect to the Arrest and Surrender of Omar Hassan Ahmad Al Bashir"), in its decision excluded any possibility for Heads of States to benefit from Head of State immunity, in order to avoid criminal prosecution, stating that: "the Chamber finds that the principle in international law is that immunity of either former or sitting Heads of State cannot be invoked to oppose a prosecution by an international court. This is equally applicable to former or sitting Heads of States not Parties to the Statute whenever the Court may exercise jurisdiction". ${ }^{21}$

On this issue is expressed too, the Constitutional Court of Albania on its 23 September, 2002 decision, with object: "Compliance with the Constitution of Albania of the Rome Statute of ICC", stating that, "immunity serves to be protected against domestic judiciary and that it emanates from the principle of separation and balance of powers" ${ }^{22}$ Also, the Constitutional Court of Albania argues that: "immunity of Heads of States belongs to national jurisdiction, and that it cannot stop the ICC, an international body, to exercise its jurisdiction over persons of this category, who have committed crimes provided by the Rome Statute." ${ }^{23}$ Accordingly, immunities or other special procedures are subject of domestic matters, concerning the relationship among equal sovereign states, not affecting the activity of a supra-national body like ICC.

\section{The Proper Interpretation and Application of Article 98 of the Rome Statute}

If we are looking for the best interpretation to attach to Article 98(1), indeed that it is pegged on the "principle of effectiveness on treaty interpretation." This principle requires a treaty to be read with all the applicable provisions of a treaty in a way which gives meaning to all of them harmoniously and is not free to adopt a reading that would result in reducing whole clauses/paragraphs of a treaty to redundancy.

Dapo Akande, in a scholarly opinion argues that the Articles of the Rome statute (Article 27 and Article 98) are not inherently irreconcilable if one adopts the principle of effectiveness on treaty interpretation. ${ }^{24}$

Since the ICC relies so much on state cooperation to effect arrest and surrender, invoking Article 98(1) conveniently defeats the core purpose of the Court.

With regard to the Rome Statute the general principles of interpretation are set out Article 21.25

However it is Article 21(3) which provides that interpretation of the laws applicable MUST be in a manner consistent with internationally recognized human rights. ${ }^{26}$

It is important to mention here that Articles $86,87,89$ (and ongoing) of the Statute, respectively obligate the States Parties to fully cooperate with the Court in all the links of criminal procedure and entitle the Court with the sole authority to make requests to States Parties for cooperation. These Articles are part of Part 9 (Nine) of the Statute (entitled "International Cooperation and Judicial Assistance"), which should be comprehended tightly related with the Preamble of the Statute, with its core meaning, objective and purpose, "the most serious crimes of concern to international community as a whole must not go unpunished and that their effective prosecution must be ensured by taking measures at the national level and by enhancing international cooperation", as stated in the Preamble. ${ }^{27}$

\footnotetext{
$20 \mathrm{lbid}$, at $18 / 22$

$21 \mathrm{Ibid}$, at 17/22, 18/22.

${ }_{22}$ Constitutional Court of Albania, decision No. 186, 23 September, 2002, (D-186/02).

${ }^{23} \mathrm{Ibid}$.

${ }^{24}$ Dapo Akande "The Legal Nature of Security Council Referrals to the ICC and its Impact on Al Bashir's Immunities" Journal of International Criminal Justice of (2009)333-352.

25 The Court shall apply:(a) In the first place, this Statute, Elements of Crimes and its Rules of Procedure and Evidence; (b) In the second place, where appropriate, applicable treaties and the principles and rules of international law, including the established principles of the international law of armed conflict; (c) Failing that, general principles of law derived by the Court from national laws of legal systems of the worldincluding, as appropriate, the national laws of States that would normally exercise jurisdiction over the crime, provided that those principles are not inconsistent with this Statute and with international law and internationallyrecognized norms and standards.

${ }^{26}$ Article 21(3)The application and interpretation of law pursuant to this article must be consistent withinternationally recognized human rights, and be without any adverse distinction founded on grounds such as gender as defined in article 7, paragraph 3, age, race, color, language, religion or belief, political or other opinion, national, ethnic or social origin, wealth, birth or other status.

${ }^{27}$ Rome Statute of the International Criminal Court, Preamble, July 17, 1998.
} 
The Court cannot fulfill its duty and its purpose without using instruments like "International Cooperation and Judicial Assistance". Without the use of this kind of instruments, the Court would be "like a paralyzed man", therefore it is crucial to the existence of the ICC and its performance, the cooperation by the States Parties, which despite Article 86 of the Statute are also obliged by international customary law.

International customary law obligates states parties to a treaty to "refrain from acts which would defeat its object and purpose." 28 Also, Article 60(3) of the Vienna Convention stipulates that "violation of a provision essential to the accomplishment of the object or purpose of the treaty" by a state party to the treaty constitutes a material breach of that treaty. ${ }^{29}$ It is a matter of fact that the prosecution procedure would "stuck", if the States Parties of the ICC would not cooperate in arresting and surrendering the perpetrators of crimes within the jurisdiction of the Court.

\section{Interpretation of the Wording Used in Article 98 (1)}

Further looking at the wording of Article 98 (1) the term 'MAY' as opposed to 'SHALL' has been used. Article 98 provides that "The Court may not proceed with a request for surrender or assistance which would require the requested State to act inconsistently with its obligations under international law with respect to the State or diplomatic immunity of a person or property of a third State, unless the Court can first obtain the cooperation of that third State for the waiver of the immunity.

Article 98 of the Rome statute is couched in discretionary terms ordinarily attributed to the verb 'MAY'. In Rastelli v Warden Metropolitan Correctional Center it was distinguished that "the use of a permissive verb-'may review' instead of 'shall review' suggests a discretionary rather mandatory review process. ${ }^{30}$

It is equally important to see what the courts said of a provision couched in mandatory terms with the verb 'shall'. A U.S court expressly stated in Lexecon,Inc v Millberg Weiss Bershand Hynes \& Lerach that the mandatory term 'shall' normally creates an obligation impervious to judicial discretion. ${ }^{31}$ The same cannot be said of Article 98(1).

Thus, it is the discretion of the court to decide whether to proceed with the request for surrender in the circumstances contemplated in Article 98(1).The court therefore can actually proceed with the request for surrender regardless of the diplomatic immunities and privileges and international law on immunities accruing to persons and third states as contemplated in Article 98(1) (supra).

Further, the Pre-Trial chamber in its decision on the failure by the Republic of Malawi to comply with cooperation request issued by the court for the arrest and surrender of Omar Hassan Ahmad Al Bashir, stated that Article 119 (1) of the Rome Statute provides that any dispute concerning the judicial function of the court be settled by the decision of the court. $^{32}$

Taken cumulatively, the Court has the final say on whether to request for assistance in terms of arrest and surrender or not.

To add on that, Judge Hans-Peter Kaul, former head of the German delegation to the preparatory

Commission of the ICC and now Judge of the ICC offered an illustration on how Germany intends to interpret Article 98. He states that under the German - ICC implementation legislation any claims of immunity will simply be rendered inadmissible when acting on the ICC request for arrest and surrender citing that it is upon the ICC to decide the existence and the scope of the immunity. ${ }^{33}$

He summarizes with the doctrine of 'who has the last say. ${ }^{34} \mathrm{He}$ rationalizes the drafters' intent as ensuring that the duty to cooperate with the court is mandatory and not elective. He argues further that if states had the last say as to whether to cooperate or not or to elect when and when not to cooperate with the ICC, the court would practically never function. 35

Judicial precedent demonstrates that immunity should not be issued to delay or even deny justice. Justice Robert Jackson while explaining immunity under the principle of 'paradox of diminishing criminal responsibility' at the Nuremberg

\footnotetext{
${ }^{28}$ Vienna Convention on the Law of Treaties, Art. 18, 26, May 23, 1969, 1155 U.N.T.S. 331, 8 I.L.M. 679.

${ }^{29} \mathrm{lbid}$, art. 60(3).

${ }^{30}$ Rastelli v Warden,Metro-Correctional Centre,782 f.2d 17.23(2d cir.1986).

31 Lexecon,Inc v Millberg Weiss Bershand Hynes \& Lerach,523,U.S 26,35(1988).

$32 \mathrm{lbid}$.

33 http://www.iccnow.org/?=judgespresidency. Last visited 25 March 2015.

${ }^{34}$ See Hans-Peter Kaulloc., cit., fn 409 para 8.

${ }_{35} \mathrm{Ibid}$.
} 
trials stated,

"We should not accept the Paradox that Legal responsibility should be the least where power is the greatest." 66 He goes further and states that, "We should stand on the principle of responsible government declared some three centuries ago to King James by the Lord Chief Justice Coke, who proclaimed that even a King is still under God and the Law."

In short, whenever immunity of whichever kind, including that fashioned within the provisions of Article 98(1) is cited in the face of crimes against humanity, this is a relic of the doctrine of the divine right of a king. The Court then should seize this singular opportunity to put an end to impunity. According to Justice Van den Wyngaert ${ }^{37}$ who wrote vehemently in dissent in the Arrest Warrant case (supra) in her words "The core problem of impunity is that national authorities that are not willing or able to investigate and prosecute crimes domestically will leave the crimes unpunished." ${ }^{38}$ However, it is Derechos who put it quite succinctly thus, "impunity is the lack of accountability for human rights violations committed, or condoned, by agents of the state." $39 \mathrm{He}$ adds that impunity "can be either de jure or de facto legitimized by amnesty laws or enshrined by corrupted or incompetent judicial systems." 40

\section{Conclusions}

In conclusion of this analysis, it is important to underline that States parties of the Rome Statute have the role of an "instrument" used by the Court in order to achieve its goals, thus the state is not exercising its national criminal jurisdiction at the moment of arresting and surrendering the Accused, because this state has delegated its criminal jurisdiction, regarding to the most serious crimes of concern to international community, to the ICC, since the moment that together with other States willed to establish this Court and its Statute.

This kind of approach is embraced by the Court too, which in "Decision on Malawi" notably held that: "it is the view of the Chamber that when cooperating with this Court and therefore acting on its behalf. States Parties are instruments for the enforcement of the jus puniendi of the international community whose exercise has been entrusted to this Court when States have failed to prosecute those responsible for the crimes within its jurisdiction."41

Thus, interpreting Article 98 in a manner that is inconsistent with the core purpose and objects of the Rome Statute as encapsulated in the preamble of the Rome Statute shall defeat the ends and needs of justice. In order to secure justice, end impunity and safeguard humanity, the correct interpretation of this article would be that which passes on the paths highlighted above.

\section{References}

Arthur Watts, The Legal position in international Law of Heads of states, Heads of Government and Foreign Ministers at P.g 82.

Dapo Akande, "The Legal Nature of Security Council Referrals to the ICC and its Impact on Al Bashir's Immunities" Journal of International Criminal Justice of (2009)333-352.

Christopher Keith Hall, "Universal Jurisdiction: The challenges for the police and the prosecuting Authorities," International Justice Project, at the second international Expert Meeting on War Crimes, Genocide and Crimes against Humanity, 16th June 2005, Interpol, Lyon: Amnesty International Al Index 1 or 53/007/2007.

George William Mugwanya, Expunging the Ghost of Impunity for Severe and Gross Violations of Human Rights and the Commission of Delicti Jus Gentium: A Case for the Domestication of International Criminal Law and the Establishment of a Strong Permanent International Criminal Court, 8 MICH. ST. U. C. L. J. INT'L L. 701, 757, 759, 778 (1999).

Derechos, 'Human Rights, What is Impunity?' June 1998 Vol. 1 No.1 Available at http://www.derechos.org/wili/l.html.J

Hans-Peter Kaulloc., cit.,fn 409 para 8.

Jürgen Bröhmer, Diplomatic Immunity, Head of State Immunity, State Immunity: Misconceptions of a Notorious Human Rights Violator, 1999, LIJL.

\footnotetext{
${ }^{36}$ Christopher Keith Hall, "Universal Jurisdiction. The challenges for the police and the prosecuting Authorities" International Justice Project, at the second international Expert Meeting on War Crimes, Genocide and Crimes against Humanity,16th June 2005, Interpol, Lyon: Amnesty International Al Index 1 or 53/007/2007.

37 ICJ ad hoc Judge.

${ }^{38}$ Dissenting opinion of Judge ad hoc Van den Wyngaert pg. 160.

${ }_{39}$ Derechos, 'Human Rights, What is Impunity?' June 1998 Vol. 1 No.1 Available at http://www.derechos.org/wi/i/l.html.J

$40 \mathrm{lbid}$.

41 ICC-02/05-01/09-139, 12-12-2011, at 20/22, 21/22.
} 
Prost and Schlunck, in Triffterer Commentary, Article $98 \mathrm{MN} 4,6$. In: Andreas L. Paulus, Legalist Groundwork for the International Criminal Court: Commentaries on the Statute of the International Criminal Court, EJIL (2003), Vol. 14 No. 4.

\section{Treaties and documents accompanying treaties}

Rome Statute of the International Criminal Court, July 17, 1998, 2187 U.N.T.S. 90; 37 I.L.M. 1002

Vienna Convention on the Law of Treaties, May 23, 1969, 1155 U.N.T.S. 331; 8I.L.M. 679

United Nations, Statute of International Court of Justice, April 18, 1946.

Vienna Convention on Diplomatic Relations 1961, United Nations, Treaty Series, vol. 500, p. 95.

Charter of the United Nations

General Assembly Resolution 58/79 December 2003

Rules of Procedure and Evidence, Official Records of the Assembly of States Parties to the Rome Statute of the International Criminal Court, First session, New York, 3-10 September 2002

\section{National and international jurisprudence}

1986, I.C.J, 14, (Nicaragua v. United States of America)

R v Bow Street Metropolitan Stipendiary Magistrate, Ex Parte Pinochet Ugarte, 3 W.L.R. 1456, (H.L. 1998)

Arrest warrant of 11 April 2000 (Democratic Republic of the Congo v. Belgium), Judgment, 14 February 2002, I.C.J. Reports 2002

ICC-02/05-01/09-139, 12-12-2011, "Decision pursuant to Article 87(7) of the Rome Statute on the Failure by the Republic of Malawi to Comply with the Cooperation Requests Issued by the Court with Respect to the Arrest and Surrender of Omar Hassan Ahmad Al Bashir"

Prosecutor v Charles Ghankay Taylor Case No.SCLSL-2002-01-1 Decision on immunity from jurisdiction, 31st May 2004.

Regina v Evans and Another and the Commissioner of Police for the Metropolis and Others Ex Parte Pinochet (On appeal from the Divisional court of the Queen's Bench Divison).

Rastelli v Warden,Metro-Correctional Centre,782 f.2d 17.23(2d cir.1986).

Lexecon, Inc v Millberg Weiss Bershand Hynes \& Lerach,523,U.S 26,35(1988).

Prosecutor v. Tihomir Blaskić, Judgment, IT-95-14-108bis: Blaskic (Interlocutory), 29 October 1997.

Constitutional Court of Albania, decision No. 186, 23 September, 2002, (D-186/02). 